\title{
Karakter Air Jatuh Dalam Membentuk Emosi Positif Menuju Relaksasi
}

\author{
I Ketut Suarna ${ }^{1}$, Prabu Wardono ${ }^{2}$, Ge Prasetyo Aditama ${ }^{3}$ \\ Email: ${ }^{1}$ suarnatp@gmail.com
}

\begin{abstract}
One of the goals of presenting water elements into interior space is to create a relaxing effect. Through 6 water feature models experiment which presents 3 chategories of spill volume, including large, medium, and small with $50 \mathrm{~cm}$ and $100 \mathrm{~cm}$ high settings, this research intended to explore the characteristic of water features that are most effective in forming positive emotions toward relaxation. The stimulus was tested to 30 respondents aged 30-45 years through quitionnaire with semantic differential method. The results of the research prove that the water sound conditioning with spills and heights setting wich affect the shape support relaxation emotions. The condition which gets the most positive response is a form of small spill with height of $50 \mathrm{~cm}$, whereas a condition which gets negative response is a form of a large spill with heights setting of $100 \mathrm{~cm}$. The tendency of perceptual responses is related to the physical characteristics of water of being light-hearted, whisper-quiet, depressed-relieved, slow-heavy which affects the assessment of emotions in the form of feeling happy, relaxed, comfortable, refreshing, sleepy, relieved and cool.
\end{abstract}

Keyword: water's characteristic, positive emotions, relaxations, interior space

\begin{abstract}
Abstrak. Salah satu tujuan menghadirkan elemen air ke dalam ruang interior adalah menciptakan efek relaksasi. Melalui eksperimen 6 model fitur air yang mewakili 3 kategori volume tumpahan, yaitu besar, sedang dan kecil dengan seting ketinggian $50 \mathrm{~cm}$ dan $100 \mathrm{~cm}$, penelitian ini ditujukan untuk mengeksplorasi karakteristik fitur air yang paling efektif dalam membentuk emosi positif menuju relaksasi. Stimulus diujikan kepada 30 responden dengan umur 30-45 tahun untuk direspon melalui media kuisioner dengan semantik differensial. Hasil penelitian membuktikan bahwa pengkondisian bunyi air dengan seting bentuk tumpahan dan ketinggian berpengaruh terhadap terbentuknya emosi yang menunjang relaksasi. Kondisi yang mendapat respon paling positif adalah bentuk tumpahan kecil dengan ketinggian $50 \mathrm{~cm}$, sedangkan kondisi yang direspon negatif adalah bentuk tumpahan besar dengan seting ketinggian $100 \mathrm{~cm}$. Kecenderungan respon persepsi terkait dengan karakteristik fisik air sebagai sifat berat-ringan, bising-tenang, berisik-hening, tertekan-lega, deras-pelan yang mempengaruhi penilaian terhadap emosi berupa perasaan senang, rileks, nyaman, menyegarkan, mengantuk, lega dan sejuk.
\end{abstract}

Kata kunci: karakter air, emosi positif, relaksasi, ruang interior

\section{A. PENDAHULUAN}

\section{Latar Belakang}

Selain berfungsi dalam memenuhi kebutuhan sehari-hari, elemen air diapresiasi dalam kaitan dengan aktifitas relegi, sebagai simbol metafisika, therapi, estetika dan kebutuhan rekreasi. Begitu penting peran dan dampak yang dirasakan dalam kehidupan sehingga elemen air kerap dihadirkan melalui manipulasi ke dalam lingkungan binaan untuk dapat dirasakan dampak positifnya setiap saat. Apresiasi, ketertarikan, serta pembahasan mengenai elemen air memberi gambaran bahwa manusia memerlukan stimulus positif dalam merestorasi prilakunya. Penelitian tentang dampak psikologis elemen air banyak dilakukan diantaranya: Suara alam terutama bunyi aliran air terbukti efektif dalam menciptakan mood dan produktivitas kerja (Jonas, 2015). Kehadiran elemen air untuk mengimbangi dan menutupi kebisingan lalu lintas perkotaan (Galbrun dan Ali, 2012), efek bunyi air di ruang terbuka juga diselidiki melalui pengukuran berbagai fitur air mancur untuk mendapatkan penilaian terhadap kesamaan dan kenyamanan (Lunden dan Nilson, 2012). Penelitian Galbrun 
dan Ali (2012) serta penelitian Lunden dan Nilson (2012) sama-sama mengindikasikan fitur air pada seting tertentu membantu menciptakan efek psikologis tertentu.

Bagaimana dengan fenomena manipulasi elemen air ke dalam ruang binaan (interior)? Kehadiran dan pemanfaatan elemen air sudah banyak dilakukan para praktisi, seperti usaha arsitek Denton Corker Marshall dengan menempatkan kolam air dipuncak gedung dan dijatuhkan sesuai hukum gravitasi, atau upaya arsitek Tadao Ando dalam karya Chuch on the water sebagai gambaran ketenangan. Pada skala kecil, fenomena manipulasi elemen air ke dalam interior sering dihadirkan melalui media akurium, air terjun mini, air jatuh pada bidang kaca, batu atau material lainya. Namun belum ada penjelasan fitur mana yang memberi efek restorasi paling baik.

Menghadirkan elemen air ke dalam ruang merupakan upaya duplikasi melalui pengolahan karakteristik dari air. Norman K. Booth (1990), menjelaskan secara umum karakteristik air dikategorikan menjadi 4 bagian

"General characteristic of water: 1. Plasticity, 2. Motion (static \& dynamic water), 3. Sound, 4. Reflectivity"

Interaksi individu dengan lingkungan ruang diawali dengan diterimanya stimulus melalui penginderaan yang diolah secara kognisi menjadi persepsi sebagai citra ruang dan pola tingkah laku. Keterlibatan sensori visual, sensori dengar dan sentuh menjadi dominasi dalam menangkap stimulus lingkungan (Hall, 1982). Dalam konteks manipulasi air ke dalam ruang interior, karakteristik air yang menjadi pertimbangan lebih dominan adalah gerakan (motion) dan bunyi air (sound).
Sementara efek bunyi sendiri dihasilkan dari gerakan airnya, sehingga penelitian ini lebih difokuskan pada karakter bunyi yang ditimbulkan dari gerakan air jatuh (yang memungkinkan diaplikasikan dalam ruangan) .

Dari uraian diatas, ada beberapa kondisi dan dugaan yang ingin diketahui lebih jauh tentang upaya memproduksi dan memanipulasi air ke dalam ruang, diantaranya :

- Gerak jatuhnya air menghasilkan bunyi yang berbeda-beda.

- Air jatuh pada seting tertentu dapat meningkatkan efek restoratif pada manusia.

- Tekanan bunyi menghasilkan warna bunyi berbeda.

- Belum ada penjelasan fitur air jatuh seperti apa yang efektif menghasilkan bunyi yang memberi dampak

- restorasi paling baik

Sehingga yang menjadi pertanyaan adalah "fitur air dengan kualitas jatuh seperti apa yang paling efektif memberi efek restorasi terhadap emosi sebagai tahapan menuju relaksasi."

\section{B. METODE PENELITIAN}

Penelitian ini merupakan penelitian eksperimen dengan metode kuantitatif dalam pengolahan data yang hasilnya dideskripsikan secara kualitatif sebagai kesimpulan.

\section{B.1 Menyiapkan Stimulus}

Merupakan

proses

mempersiapkan model air jatuh (fitur air jatuh), mengukur dan merekam bunyi air yang dihasilkan dari model yang dibuat. Model (fitur) dikelompokkan dalam 3 kategori sebagai volume besar (tumpahan lebar), volume sedang (tumpahan beberapa titik), dan volume kecil (tumpahan 1 
titik).

Karena gerakan air (perpindahan dari tempat yang lebih tinggi ke tempat yang lebih rendah) di kategorikan sebagai gerakan dinamis (Booth, 1990) maka bunyi air dikaitkan dengan tinggi atau rendahnya tumpahan, sehingga kategori volume dikombinasikan dengan tinggi rendahnya tumpahan, yaitu:

Kategori I, volume air yang besar (bentuk tumpahan lebar) dikombinasi dengan ketinggian menjadi:

- Model dengan tumpahan air lebar dan seting rendah $(50 \mathrm{~cm})$ yang akan disebut Kondisi 1.

- Model dengan tumpahan air lebar dan seting tinggi $(100 \mathrm{~cm})$ yang akan disebut Kondisi 2.
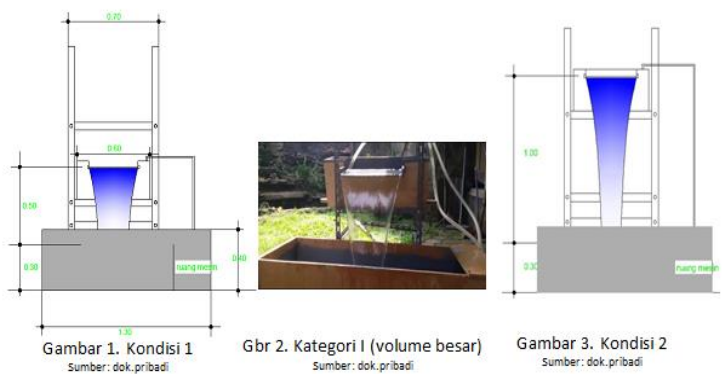

Kategori II, volume air yang sedang (bentuk tumpahan beberapa titik) dikombinasi dengan ketinggian menjadi:

- Model dengan tumpahan air beberapa titik dan seting rendah $(50 \mathrm{~cm})$ yang akan disebut Kondisi 3.

- Model dengan tumpahan air beberapa titik dan seting tinggi $(100 \mathrm{~cm})$ yang akan disebut Kondisi 4.

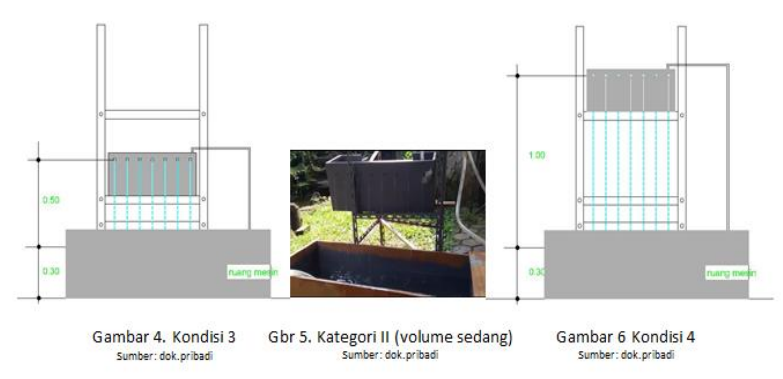

Kategori III, volume air yang kecil (bentuk tumpahan 1 titik ) dikombinasi dengan ketinggian menjadi:

- Model dengan bentuk tumpahan air 1 titik dengan seting rendah yang akan disebut sebagai Kondisi 5

- Model dengan bentuk tumpahan air 1 titik dengan seting tinggi yang akan disebut sebagai Kondisi 6

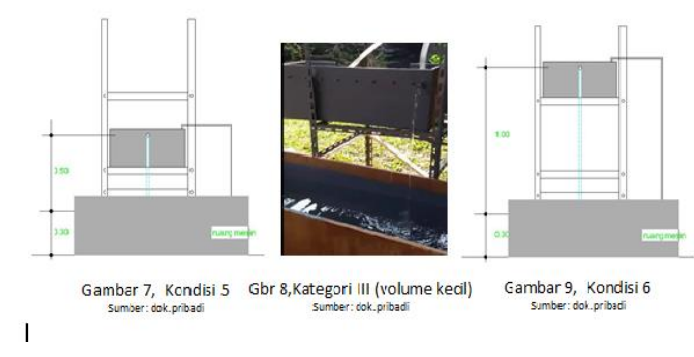

Selanjutnya bunyi masing-masing fitur air jatuh direkam dengan mikrofon ECM 8000 Behringer dan recorder Zoom H6 diolah melalui software Audacity untuk menghasilkan rekaman yang akan dijadikan stimulus untuk uji subyektif. Masing-masing stimulus memiliki warna yang berbeda, seperti yang digambarkan pada grafik spektrum di bawah.

- Pada frekuensi rendah (100-400 $\mathrm{Hz}$ ), kondisi 1 memiliki level energi atau tingkat tekanan suara $65,1 \mathrm{~dB}$, kondisi $2=69,3 \mathrm{~dB}$, kondisi $3=$ $62,3 \mathrm{~dB}$, kondisi $4=66,7 \mathrm{~dB}$, kondisi $5=57,6 \mathrm{~dB}$ dan kondisi $6=$ 60,5 dB

- Pada frekuensi menengah (500$1600 \mathrm{~Hz}$ ), kondisi 1 memiliki level energi atau tingkat tekanan suara $62,4 \mathrm{~dB}$, kondisi $2=68,2 \mathrm{~dB}$, kondisi $3=70,9 \mathrm{~dB}$, kondisi $4=$ $72,8 \mathrm{~dB}$, kondisi $5=56,6 \mathrm{~dB}$ dan kondisi 6 


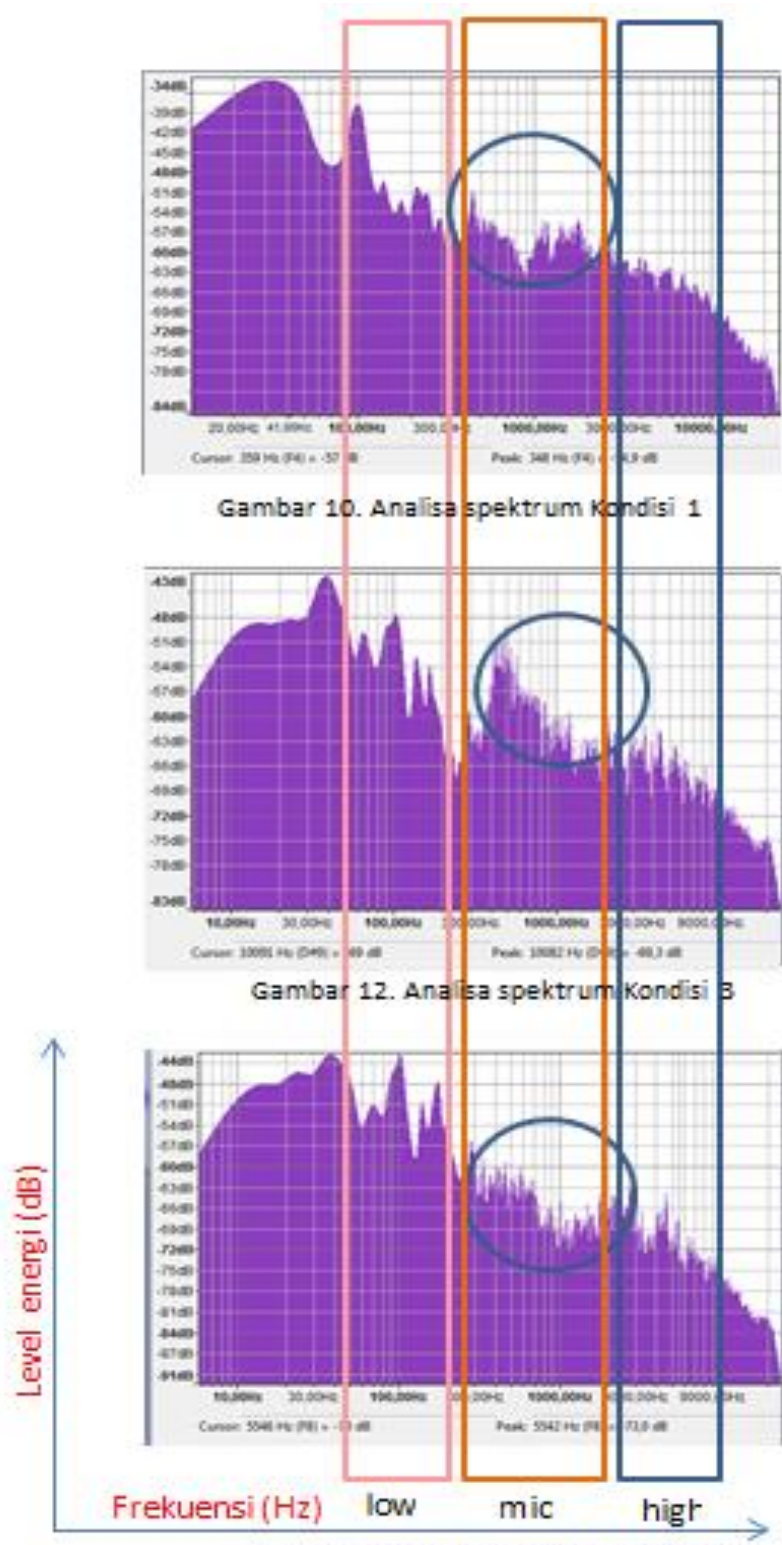

Gambar 14. Analisa spektrum Kondisi 5

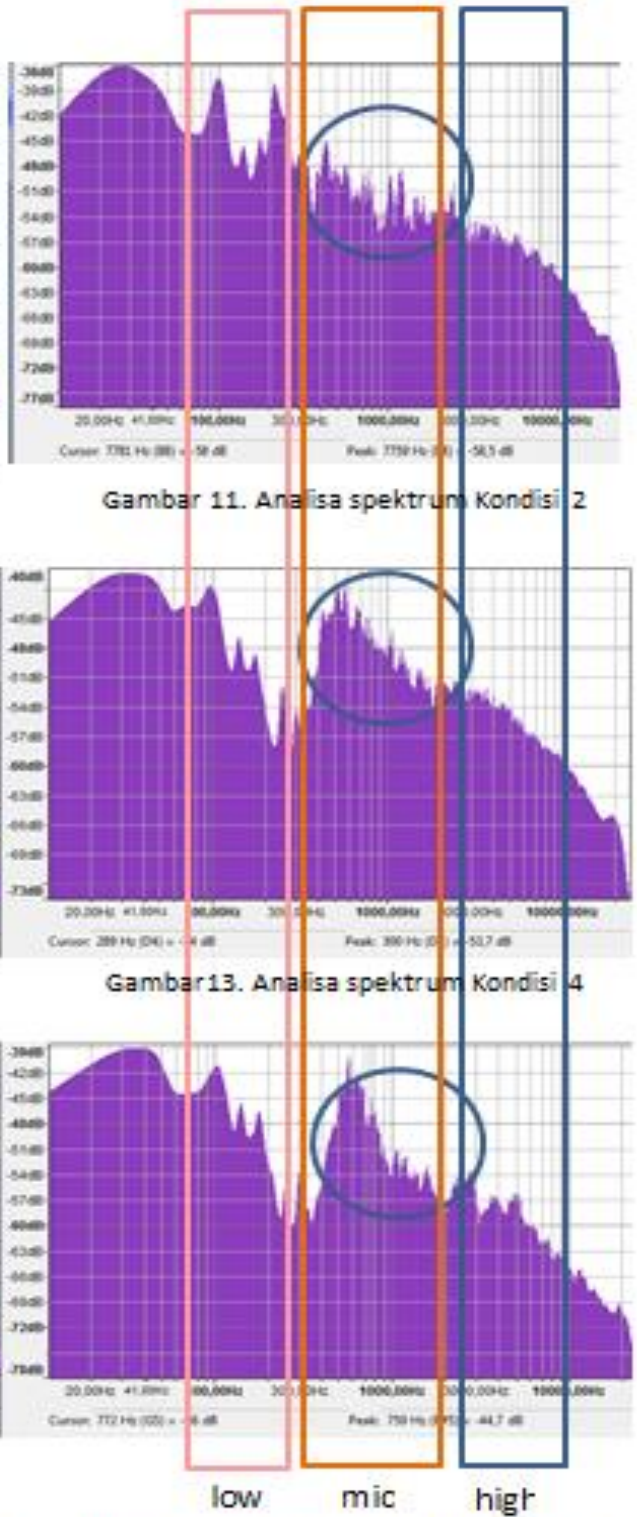

Gambar 15. Analisa spektrum Kondisi 6

\begin{tabular}{|c|c|c|c|c|c|c|c|c|c|c|c|c|c|}
\hline \multicolumn{8}{|c|}{ 1/30ktat } & & \multirow[b]{2}{*}{ kondlal 2} & \multirow[b]{2}{*}{ kondisl 3} & \multirow{3}{*}{$\begin{array}{l}\text { konds: } 4 \\
1395551,7\end{array}$} & \multirow[b]{2}{*}{ kondlal 5} & \multirow[b]{2}{*}{ kondisil 6} \\
\hline & Iondisi 1 & londisil 2 & kondlal 3 , & londsel 4 & londisis & londs: 6 & & & & & & & \\
\hline & 63,4 & 63.4 & . $\quad 38,3$ & 514 & $\mathbf{3}, 8$ & 559 & 561 & 2178136 & 2192523,7 & ש6s:95,1 & & 238395 & 3928941 \\
\hline 225 & 533 & 531 & 30,8 & 57,5 & 40,8 & 508 & 346 & 214055 & 20568973 & 1201529 & 33674447 & 39949,35 & 12039145 \\
\hline 150 & 51,5 & 535 & 30,2 & 57,2 & $4 \pi, 9$ & 490 & 509 & 2423855 & 338131,39 & 2052315 & 52123205 & $61090, \pi$ & 78990,987 \\
\hline 200 & 528 & 633 & 49,3 & 524 & 4,4 & 45,6 & 470 & 2922504 & 216598 & 3445,05 & 173362,42 & 27009,29 & 36337,523 \\
\hline 250 & 53.4 & 62,5 & 51,1 & 53.2 & 46,5 & 437 & 425 & 2190053 & $190 \pi x, 4$ & 1230003 & $20 \pi 78,8$ & 4751 포 & 20545,508 \\
\hline 315 & 500 & 585 & 51,6 & 537 & 48,3 & 481 & 425 & 2004796 & 70002859 & 143679 & 234725,21 & $6 / 341,15$ & E851,585 \\
\hline 400 & 522 & 601 & 36,6 & 619 & 20,2 & 550 & 410 & 157355,7 & 100350,9 & 452436 & 1359002,5 & $32 x 3,34$ & $4024 \mathbb{B}, 1$ \\
\hline 300 & 541 & 601 & 54.8 & 65,9 & 20,3 & 595 & 454 & 2559879 & $10175 x, 6$ & 2999025 & $334 \times x, 5$ & 899947 & $900 \equiv 278$ \\
\hline Ex & 331 & 593 & $\boldsymbol{\omega , 5}$ & 65,5 & 30,0 & 359 & 565 & 2057981 & 247782,21 & 2479157 & 403093 & 990811 & 391987,23 \\
\hline 300 & 512 & 59.7 & $E, 2$ & 65,5 & 47,1 & 55.7 & 75,5 & 1323692 & 94374949 & 2083852 & 338422,3 & 51879,32 & 36958342 \\
\hline 1000 & 537 & 604 & 99.8 & 649 & 46,6 & 538 & 940 & 2352904 & 108790,9 & 96035,3 & 3069619,9 & 46120,39 & 24196308 \\
\hline 1250 & 355 & 617 & $\omega 0,0$ & 63,0 & $\Delta 3,2$ & 529 & 737 & $355<37,5$ & 1463534,2 & $98937 / 4$ & 2003029 & 657305 & 29318994 \\
\hline 1500 & 57,5 & 511 & 99,4 & 630 & 30,4 & 535 & 35.5 & 308013 & 1296513,1 & $370 x$ & $1998 \times 24,7$ & 209005 & 22401815 \\
\hline 2000 & 563 & 620 & 990 & 641 & 52.8 & 553 & 524 & 283105 & 1383451,3 & 3032405 & 2349868,1 & 2904837 & $33 \pm 33,3$ \\
\hline 2300 & 567 & 632 & $\mathbf{\alpha}, 3$ & 649 & 34.4 & 544 & 390 & 472400 & 209198,6 & 2702518 & $30656 \pm 5$ & $27 \times 126$ & 27520508 \\
\hline 3150 & 562 & 619 & $\omega 0,2$ & 65,3 & $\mathbf{3 2 , 5}$ & 367 & 347 & 4142522 & 1552839 & 2045015 & 3395100,5 & 19092,8 & 47039897 \\
\hline 4000 & 553 & 629 & 00,9 & 650 & 30,3 & $57 / 4$ & 307 & 058138 & 197130,2 & 1235075 & $312 \pi 72,4$ & 214819 & 55353653 \\
\hline 5000 & 561 & 626 & $\mathbf{Q}, 1$ & 64.6 & $\mathbf{3}, 7$ & 57,2 & 294 & 409057,2 & 1812133,7 & 251220 & 291213,2 & 24123 & 525032,8 \\
\hline \multirow{2}{*}{$\begin{array}{l}5300 \\
5000\end{array}$} & 561 & 627 & $\omega 0,0$ & 640 & 51,5 & 564 & 315 & 4047245 & 1345430,2 & 9974854 & $25135 \pi / 4$ & 2421459 & 23245172 \\
\hline & 35,5 & 622 & 38,5 & 637 & 30,6 & 565 & 29.1 & 35950 & 16ธนณ,1 & r2seg 1 & 2369496,5 & 1138335 & $442 \pi 27,87$ \\
\hline 10000 & 545 & 51.5 & 50,7 & 63,3 & 20,5 & 55,5 & 288 & 2832001 & 103819,2 & 3051783 & 213919,5 & 30437 & 355067,45 \\
\hline 12300 & 52,4 & 599 & 36,9 & 619 & $\Delta 8,1$ & 540 & 258 & & & & & & \\
\hline 16000 & 498 & 57,5 & $\mathbf{5 6 , 7}$ & 60,2 & 46,5 & 528 & 254 & & & & & & \\
\hline 20000 & 485 & 565 & 56,3 & 59.8 & 5,9 & 528 & 267 & & & & & & \\
\hline
\end{tabular}




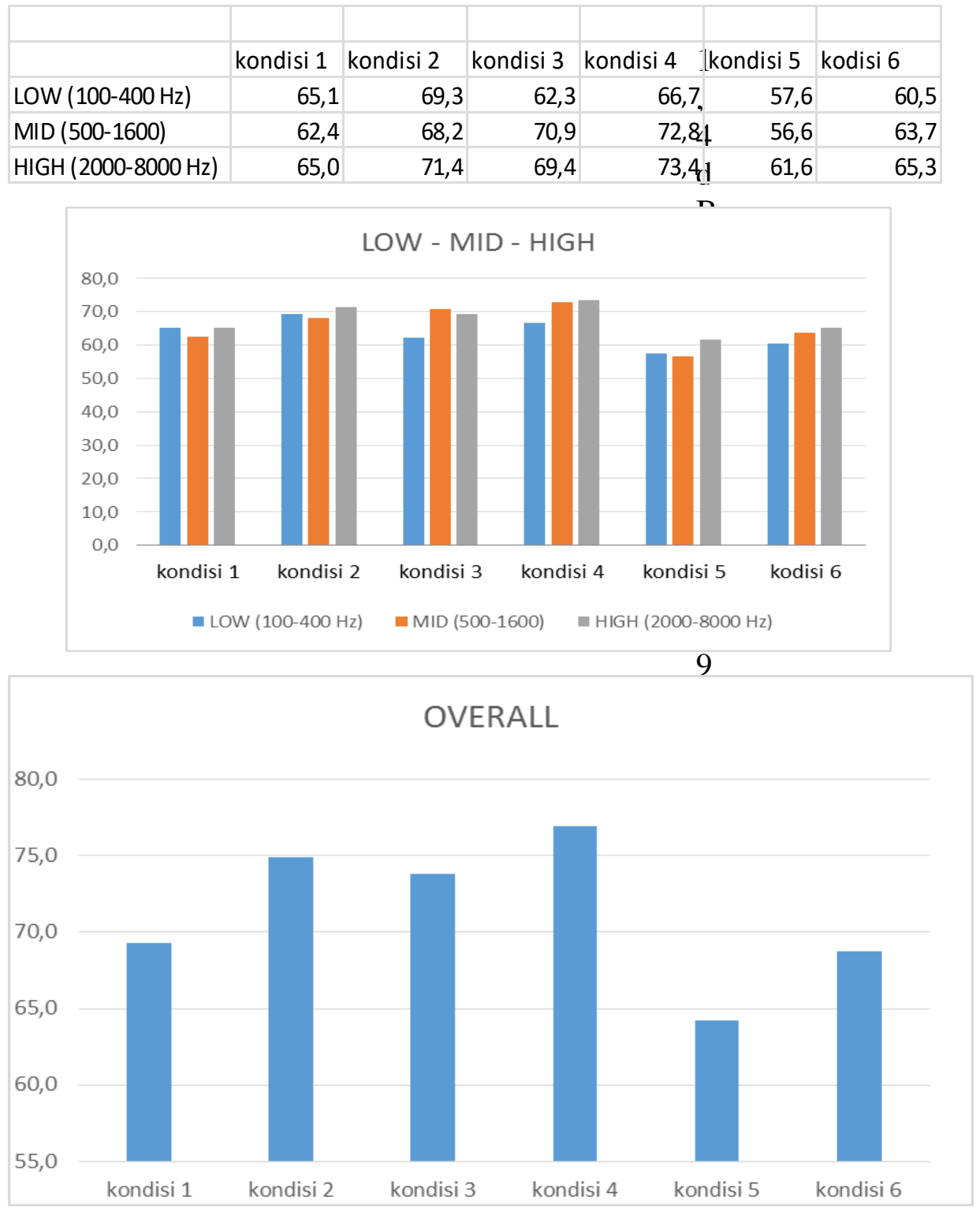

7

Gambar 16,17,18, hasil pengolahan data menggunakan Matlab, sumber: dok. , Pribadi

\begin{tabular}{|l|r|r|r|r|r|r|}
\hline & & & & & \\
\hline & kondisi 1 & kondisi 2 & kondisi 3 & kondisi 4 & kondisi 5 & kondisi 6 \\
\hline $\begin{array}{l}\text { Keseluruhan } \\
\text { kondisi }\end{array}$ & 69,3 & 74,9 & 73,8 & 76,9 & 64,2 & 68,7 \\
\hline
\end{tabular}

Gambar 19, 20, hasil pemgolahan data Matlab untuk semua frekuensi, sumber :dokumen pribadi 
Pada semua frekuensi, level energi atau tingkat tekanan suara masing-masing kondisi tercatat: kondisi $1=69,3 \mathrm{~dB}$, kondisi $2=74,9 \mathrm{~dB}$, kondisi $3=73,8 \mathrm{~dB}$, kondisi $4=76,9$ $\mathrm{dB}$, kondisi $5=64,2 \mathrm{~dB}$ dan kondisi $6=$ $68,7 \mathrm{~dB}$.

\section{B.2 Pengujian Stimulus}

Pengambilan data melibatkan 30 orang responden yang terdiri dari 18 laki-laki dan 12 perempuan dengan rentang umur 30 - 45 tahun. Data yang diukur terkait respon persepsi dan respon emosi. Respon persepsi dikaitkan dengan atribut fisik berupa kualitas bunyi air (ketajaman, kasarhalus, kecepatan yang dikaitkan dengan deras atau pelan dan variasi bunyi yang yang dikaitkan dengan konstan atau bervariasinya bunyi). Sementara penilaian terhadap respon emosi dikaitkan dengan dampak ketenangan, rileks, alami, familiar, kesegaran, senang dan tegang (Calarco dan Galbrun, 2014)

Setiap fitur bunyi air di loop dengan durasi 5 menit, pada menit ketiga responden sudah boleh mengisi kuisioner. Setiap fitur dijalankan pada durasi 5 menit dan break 1 menit untuk pergantian fitur berikutnya. Setiap menyelesaikan 3 fitur bunyi dilakukan break selama 5 menit untuk memulihkan atau menormalisasi dari persepsi sebelumnya. Kemudian dilanjutkan pada 3 fitur berikutnya. Setelah memahami prosedur eksperimen, responden bersiap untuk memasuki pengambilan data utama. Lembar kuisioner dibagikan untuk setiap satu fitur bunyi air. Responden diharapkan duduk sesantai mungkin agar lebih fokus pada sensori pendengaran. Kuisioner diisi setiap menyelesaikan satu uji listening

\section{HASIL PENELITIAN}

C.1. Hasil Pengujian terhadap Respon
Persepsi

Hasil uji multiple comparisons Bonferroni menunjukkan hasil sebagai berikut

\begin{tabular}{|c|c|c|c|c|c|c|}
\hline \multirow[b]{2}{*}{ (1) kpods:s] } & \multirow[b]{2}{*}{ (J) $\left.k_{0} 00015\right]$} & \multirow{2}{*}{$\begin{array}{c}\text { Mean } \\
\text { Ditrerence }(\mathrm{l}-\mathrm{V})\end{array}$} & \multirow[b]{2}{*}{ Sov. Error } & \multirow[b]{2}{*}{ sig. } & \multicolumn{2}{|c|}{$95 \%$ Contoence Interval } \\
\hline & & & & & Lower Bound & Upper Bound \\
\hline \multirow[t]{5}{*}{1} & 2 & 6,333 & 1,885 & .014 & .72 & 11.94 \\
\hline & 3 & 1.267 & 1,885 & 1,000 & $-4,34$ & 6.88 \\
\hline & 4 & 2,900 & 1,885 & 1,000 & $-2,71$ & 8.51 \\
\hline & 5 & $-11,900^{\circ}$ & 1,885 & .000 & $-17,51$ & -6.29 \\
\hline & 6 & $-6,6000$ & 1,825 & .009 & -12.21 & -99 \\
\hline \multirow[t]{5}{*}{2} & 1 & $-6,333$ & 1,285 & .014 & $-11,94$ & -.72 \\
\hline & 3 & -5.067 & 1.825 & .118 & $-10,68$ & .54 \\
\hline & 4 & $-3,433 \mid$ & 1,835 & 1.000 & $-9,04$ & 2,18 \\
\hline & 5 & $-18.233^{\circ}$ & 1,835 & .000 & -23.84 & $-12,62$ \\
\hline & 6 & $-12.933^{\circ}$ & 1,835 & .000 & -18.54 & $-7,32$ \\
\hline \multirow[t]{5}{*}{3} & 1 & $-1,257$ & 1,885 & 1.000 & -6.88 & 4,34 \\
\hline & 2 & 5.067 & 1,825 & .118 & -54 & 10.68 \\
\hline & 4 & 1.633 & 1,885 & 1,000 & $-3,98$ & 7,24 \\
\hline & 5 & $-13,16 \pi$ & 1,825 & .000 & $-18,78$ & $-7,56$ \\
\hline & 6 & $-7,267$ & 1,805 & .001 & $-13,48$ & -2.26 \\
\hline \multirow[t]{5}{*}{4} & 1 & $-2,900$ & 1,805 & 1.000 & $-8,51$ & 2,71 \\
\hline & 2 & 3,433 & 1,805 & 1,000 & $-2,18$ & 9.04 \\
\hline & 3 & $-1,633$ & 1,885 & 1,000 & $-7,24$ & 3,98 \\
\hline & 5 & $-14,000^{\circ}$ & 1,285 & .000 & $-20,41$ & $-9,19$ \\
\hline & 6 & $-9,500^{\circ}$ & 1,825 & .000 & $-15,11$ & -3.89 \\
\hline \multirow[t]{5}{*}{5} & 1 & $11,900^{\circ}$ & 1,825 & .000 & 6.29 & 17,51 \\
\hline & 2 & $18.233^{\circ}$ & 1,835 & .000 & 12.62 & 23.84 \\
\hline & 3 & $13,16 \mathrm{~T}$ & 1,885 & .000 & 7,56 & 18,78 \\
\hline & 4 & $14.200^{\circ}$ & 1,805 & .000 & 9,19 & 20,41 \\
\hline & 6 & 5,300 & 1,835 & .062 & -31 & 10.91 \\
\hline \multirow[t]{5}{*}{6} & 1 & $6,600^{\circ}$ & 1.885 & .009 & .99 & 12.21 \\
\hline & 2 & $12.933^{\circ}$ & 1,805 & .000 & 7,32 & 18,54 \\
\hline & 3 & 7.257 & 1,805 & .001 & 2.26 & 13,48 \\
\hline & 4 & $9,500^{\circ}$ & 1,885 & .000 & 3,39 & 15,11 \\
\hline & 5 & $-5,300$ & 1,885 & .082 & $-10,91$ & .31 \\
\hline
\end{tabular}

-The mean d dterence is signitcant at the 0.05 level.

Gambar 21. Multiple comparisons Persepsi (SPSS). Sumber :dokumen

Tabel diatas menggambarkan perbedaan signifikansi setiap korelasi. Perbedaan respon persepsi dapat dikatakan signifikan dengan nilai $\mathrm{p}<$ 0.05 sedang nilai respon $p>0,05$ dikatakan tidak signifikan. Hubungan tiap pair dalam tabel dapat digambarkan sebagai berikut

Perbedaan signifikan terjadi pada korelasi antara:

Kondisi 1 dengan kondisi 2, 5 \& 6 Kondisi 2 dengan kondisi 1, 5 \& 6 Kondisi 3 dengan kondisi 5 \& 6 Kondisi 4 dengan kondisi 5 \& 6 Kondisi 5 dengan kondisi 1,2,3 \& 4 Kondisi 6 dengan kondisi 1,2,3 \& 4 Sedangkan korelasi antara beberapa pair tidak memiliki respon perbedaan persepsi yang signifikan, diantaranya:

Kondisi 1 dengan kondisi 3 \& 4 
Kondisi 2 dengan kondisi 3, 4 \& 5 Kondisi 3 dengan kondisi 1, 2 \& 4

Kondisi 4 dengan kondisi 1, 2 \& 3

Kondisi 5 dengan kondisi 6

Kondisi 6 dengan kondisi 5

Perubahan respon ke arah negatif atau positif dapat dilihat melalui skor pada kolom mean, apabila mengandung nilai negatif (-), maka subyek melakukan peningkatan nilai respon dan jika skor mengandung nilai positif artinya subyek melakukan penurunan nilai respon

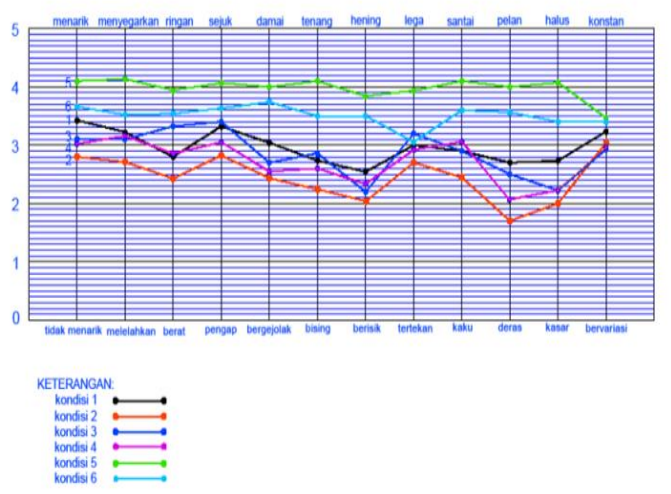

Gambar 22. Grafik perbandingan respon persepsi Sumber : dokumen pribadi

Kondisi 5 dan 6 berada diatas batas netral (skala 3), kondisi 2 dan 4 berada dibawah batas netral sementara kondisi 1 dan 3 berada disekitar garis netral. Diagram diatas menunjukkan bahwa kondisi 5 ( tumpahan 1 titik dengan ketinggan $50 \mathrm{~cm}$ ) mendapat respon paling tinggi atau respon paling positif, sedangkan kondisi 2 (tumpahan beberapa titik dengan ketinggian $100 \mathrm{~cm}$ ) mendapat respon paling rendah atau respon paling negatif. Emosi

C.2. Hasil Pengujian terhadap

\section{a. Uji Normalitas}

Hadirnya elemen alam berupa bunyi air diharapkan menjadi stimulus yang berpengaruh pada emosi dalam menunjang keinginan untuk relaksasi.
Uji Anova terhadap respon emosi dilakukan untuk mengetahui interaksi antar variabel dan pengaruhnya terhadap perlakuan. Sebagai langkah awal dari langkah uji Anova adalah uji normalitas untuk mengetahui distribusi data apakah normal atau tidak.

\begin{tabular}{|c|c|c|c|c|c|c|c|}
\hline & & $\begin{array}{c}\text { kondisi } \\
1\end{array}$ & $\begin{array}{c}\text { kondisi } \\
2 \\
\end{array}$ & $\begin{array}{c}\text { kondisi } \\
3 \\
\end{array}$ & $\begin{array}{c}\text { kondisi } \\
4 \\
\end{array}$ & $\begin{array}{c}\text { kondisi } \\
5 \\
\end{array}$ & $\begin{array}{c}\text { kondisi } \\
6 \\
\end{array}$ \\
\hline $\mathrm{N}$ & & 30 & 30 & 30 & 30 & 30 & 30 \\
\hline \multirow[t]{2}{*}{ Normal Parameters } & Mean & 36,57 & 31,90 & 36,50 & 38,63 & 46,60 & 42,10 \\
\hline & $\begin{array}{l}\text { Std. } \\
\text { Deviation }\end{array}$ & 7,614 & 7,707 & 7,310 & 8,418 & 6,279 & 9,654 \\
\hline MostExtreme & Absolute & ,126 & 180 & ,107 & ,131 & .165 & 188 \\
\hline \multirow[t]{2}{*}{ Differences } & Positive & ,126 & 180 & ,107 & ,093 & ,108 & 109 \\
\hline & Negative & -108 & -124 &,- 081 & -131 & -165 & -188 \\
\hline Test Statistic & & ,126 & 180 & , 107 & 131 & ,165 & 188 \\
\hline $\mathrm{ymp} \mathrm{Si}$ & & $200 \mathrm{cs}$ & ,014 & ,200cad & , $199^{\circ}$ & ,036 & \\
\hline
\end{tabular}

Gambar 23. Uji normalitas (SPSS), sumber:dokumen pribadi

Hasil uji normalitas menunjukkan kondisi 1, kondisi 3, dan kondisi 4 memiliki nilai sig. > 0.05 sedangkan kondisi 2, kondisi 5 dan kondisi 6 memiliki nilai sig. $<0.05$.

Dari hasil penghitungan nilai rata-rata dari masing-masing persepsi terhadap ke enam stimulus yang diujikan, menunjukkan semakin tinggi nilai rata-rata/ mean dari sebuah kondisi maka semakin positif pula respon persepi yang dihasilkan. Semakin besar nilai standar deviasi menandakan variasi respon yang berbeda terhadap kondisi tersebut, penilaian yang diberikan ada yang tinggi ataupun terlalu rendah. Pengukuran terhadap responden mencatat hasil sebagai berikut: kondisi 1 memiliki Standar Deviasi $(\mathrm{SD})=$ 7,614, kondisi $2(\mathrm{SD})=7,707$, kondisi $3(\mathrm{SD})=7,310$, kondisi $4(\mathrm{SD})=$ 8,418 , kondisi $5(\mathrm{SD})=6.279$, dan kondisi 6 dengan standar deviasi (SD) $=9,654$. Kondisi 6 (Tumpahan 1 titik, $100 \mathrm{~cm}$ ) memiliki standar deviasi paling tinggi, artinya Kondisi 6 mendapat respon yang paling bervariasi, responden memberi penilaian yang rendah ataupun sebaliknya cukup tinggi. 


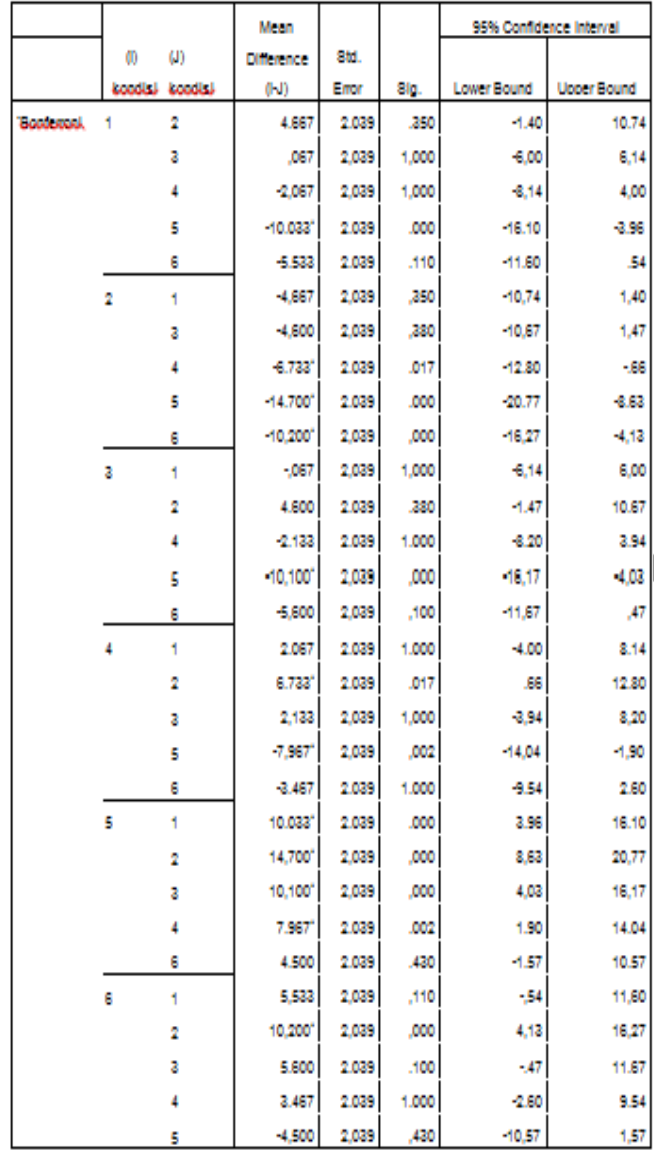

Tabeld i at a s .menggambarkan perbedaan signifikansi setiap korelasi. Perbedaan respon emosi dapat dikatakan signifikan dengan nilai $\mathrm{p}<$ 0.05 sedang nilai respon $\mathrm{p}>0,05$ dikatakan tidak signifikan. Hubungan tiap pair dalam tabel dapat digambarkan sebagai berikut:

Perbedaan signifikan terjadi pada korelasi antara:

- Kondisi 1 dengan kondisi 5

- Kondisi 2 dengan kondisi 4 Kondisi 2 dengan kondisi 5 Kondisi 2 dengan kondisi 6

- Kondisi 3 dengan kondisi 5

- Kondisi 4 dengan kondisi 2 Kondisi 4 dengan kondisi 5

- Kondisi 5 dengan kondisi 1 Kondisi 5 dengan kondisi 2 Kondisi 5 dengan kondisi 3 Kondisi 5 dengan kondisi 4

- Kondisi 6 dengan kondisi 2
Sedangkan korelasi antara beberapa pair tidak memiliki respon perbedaan emosi yang signifikan, diantaranya:

- Kondisi 1 dengan kondisi 2 Kondisi 1 dengan kondisi 3 Kondisi 1 dengan kondisi 4 Kondisi 1 dengan kondisi 6

- Kondisi 2 dengan kondisi 1 Kondisi 2 dengan kondisi 3

- Kondisi 3 dengan kondisi 1 Kondisi 3 dengan kondisi 2

- Kondisi 3 dengan kondisi 4

- Kondisi 3 dengan kondisi 6

- Kondisi 4 dengan kondisi 1 Kondisi 4 dengan kondisi 3 Kondisi 4 dengan kondisi 6

- Kondisi 5 dengan kondisi 1 Kondisi 5 dengan kondisi 2 Kondisi 5 dengan kondisi 3 Kondisi 5 dengan kondisi 4

- Kondisi 6 dengan kondisi 1 Kondisi 6 dengan kondisi 3 Kondisi 6 dengan kondisi 4 Kondisi 6 dengan kondisi 5

Kondisi 4, 5 dan 6 rata-rata berada diatas garis batas netral (skala 3 ), kondisi 2 berada dibawah batas netral sementara kondisi 1 dan 3 berada disekitar garis netral. Diagram diatas menunjukkan bahwa kondisi 5 ( tumpahan 1 titik dengan ketinggan $50 \mathrm{~cm} \mathrm{)} \mathrm{mendapat} \mathrm{respon} \mathrm{paling} \mathrm{tinggi}$ atau respon paling positif, sedangkan kondisi 2 (tumpahan beberapa titik dengan ketinggian $100 \mathrm{~cm}$ ) mendapat respon paling rendah atau respon paling negatif

Kondisi 4, 5 dan 6 rata-rata berada diatas garis batas netral (skala 3), kondisi 2 berada dibawah batas netral sementara kondisi 1 dan 3 berada disekitar garis netral. Diagram diatas menunjukkan bahwa kondisi 5 (tumpahan 1 titik dengan ketinggan $50 \mathrm{~cm}$ ) mendapat respon paling tinggi atau respon paling positif, sedangkan kondisi 2 (tumpahan beberapa titik 
dengan ketinggian $100 \mathrm{~cm}$ ) mendapat respon paling rendah atau respon paling negatif.

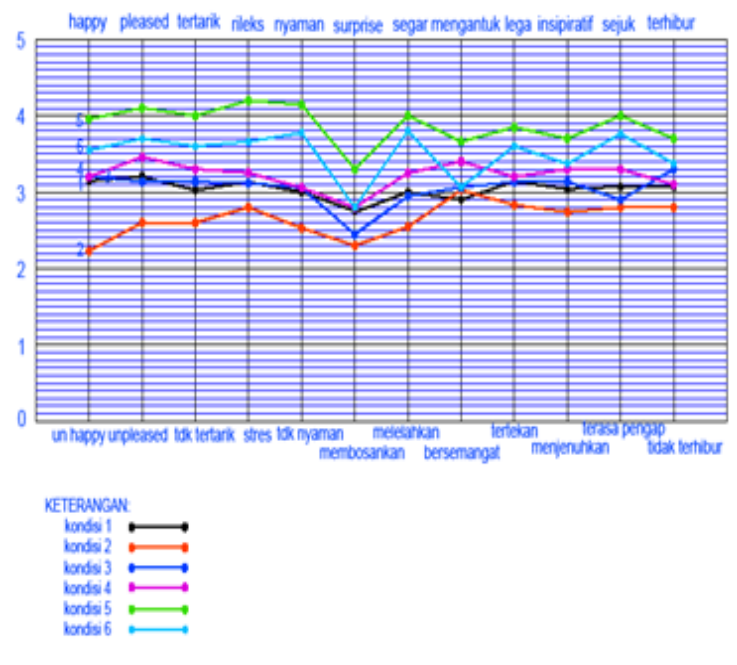

\section{Gambar 25. Grafik perbandingan respon Emosi Sumber : dokumen pribadi}

Interaction Effect Responden

\begin{tabular}{|c|c|l|c|l|c|}
\hline \multicolumn{2}{|c|}{ Kondisi } & \multicolumn{2}{|c|}{ Respon Persepsi } & \multicolumn{2}{c|}{ Respon Emosi } \\
\hline \multirow{4}{*}{1} & $\mathbf{2}$ & Signifikan & + & Tidak signifikan & - \\
\cline { 2 - 6 } & $\mathbf{3}$ & Tidak signifikan & - & Tidak signifikan & - \\
\cline { 2 - 6 } & $\mathbf{4}$ & Tidak signifikan & - & Tidak signifikan & - \\
\cline { 2 - 6 } & $\mathbf{5}$ & Signifikan & + & Signifikan & + \\
\cline { 2 - 6 } & $\mathbf{6}$ & Signifikan & + & Tidak signifikan & - \\
\hline \multirow{4}{*}{2} & $\mathbf{3}$ & Tidak signifikan & - & Tidak signifikan & - \\
\cline { 2 - 6 } & $\mathbf{4}$ & Tidak signifikan & - & Signifikan & + \\
\cline { 2 - 6 } & $\mathbf{5}$ & Signifikan & + & Signifikan & + \\
\cline { 2 - 6 } & $\mathbf{6}$ & Signifikan & + & Signifikan & + \\
\hline \multirow{3}{*}{3} & 4 & Tidak signifikan & - & Tidak signifikan & - \\
\cline { 2 - 6 } & $\mathbf{5}$ & Signifikan & + & Signifikan & + \\
\cline { 2 - 6 } & $\mathbf{6}$ & Signifikan & + & Tidak signifikan & - \\
\hline \multirow{2}{*}{4} & $\mathbf{5}$ & Signifikan & + & Signifikan & + \\
\cline { 2 - 6 } & $\mathbf{6}$ & Signifikan & + & Tidak signifikan & - \\
\hline $\mathbf{5}$ & $\mathbf{6}$ & Tidak signifikan & - & Tidak signifikan & - \\
\hline
\end{tabular}

Gambar 26. Korelasi antar kondisi Sumber; dokumen pribadi

\section{PEMBAHASAN}

\section{D.1. Pembahasan Efek Interaksi antar Kondisi}

1. Kondisi 1 dibandingkan dengan kondisi 2

Kedua kondisi memiliki bentuk tumpahan yang sama yaitu melebar dan solid dengan debit air besar, namun berbeda pada setting ketinggian. Kondisi 1 disetting pada ketinggian 50 $\mathrm{cm}$ sedangkan kondisi 2 disetting pada ketinggian $100 \mathrm{~cm}$. Kondisi 1 direspon lebih positif dibanding kondisi 2. Hal ini dipengaruhi perbedaan seting ketinggian, tumpahan yang semakin tinggi mengakibatkan tekanan ke tangki bawah lebih berat, menjadikan bunyi terasa kasar dan deras sehingga responden cenderung merasa tertekan, ketidaknyamanan, perasaan tidak senang ataupun stress.

2. Kondisi 1 dibandingkan dengan kondisi 3

Kedua jenis respon (persepsi dan emosi) memperlihatkan hasil yang sama yaitu tidak signifikan. Kedua kondisi sama-sama disetting pada ketinggian $50 \mathrm{~cm}$ yang berbeda adalah bentuk tumpahannya. Kondisi 1 memiliki bentuk tumpahan melebar dan solid dengan debit air tumpahnya besar, sedangkan kondisi 3 memiliki bentuk tumpahan beberapa titik. Bunyi bervariasi yang dihasilkan dari tumpahan beberapa titik cenderung dinilai bergejolak, bising, berisik yang mempengaruhi emosi responden pada perasaan yang tidak nyaman atau kurang menyenangkan. Walaupun disetting pada ketinggian yang sama, bunyi pada kondisi 3 dirasakan lebih tajam dan cenderung memiliki frekuensi lebih tinggi dari variasi gemericik tumpahannya. Dalam penelitiannya, Galbrun (2014) menyebut bahwa frekuensi rendah lebih efektif dalam memberi efek terhadap ketenangan dan relaksasi. Frekuensi rendah cenderung dihasilkan antara tumapahan air media air dari pada benda - benda keras seperti jatuhnya air pada kerikil yang menghasilkan efek suara lebih nyaring. Terkait dengan tumpahan yang rendah, bunyi yang dihasilkan cenderung lebih lembut dan halus. Berbeda dengan temuan Watt (2009) tumpahan tinggi menghasilkan fenomena gelombang dan gelembung sehingga suara yang 
dihasilkan lebis bervariasi.

3. Kondisi 1 dibandingkan dengan kondisi 4

Sama halnya dengan perbandingan kondisi 1 dan 3, perbandingan kondisi 1 dengan kondisi 4 juga memiliki nilai yang sama. Kedua jenis respon (persepsi dan emosi) memperlihatkan hasil tidak signifikan. Kondisi 1 memiliki bentuk tumpahan melebar dan solid dengan debit air tumpahnya besar, sedangkan kondisi 4 memiliki bentuk tumpahan beberapa titik. Kondisi 1 disetting pada ketinggian $50 \mathrm{~cm}$ sedangkan kondisi 4 diseting pada ketinggian $100 \mathrm{~cm}$. Setelah responden merespon kondisi 1 kemudian berpindah merespon kondisi 4 terjadi penurunan nilai respon. Bunyi bervariasi yang dihasilkan dari tumpahan beberapa titik cenderung dinilai bergejolak, bising, berisik yang mempengaruhi emosi responden pada perasaan yang tidak nyaman atau kurang menyenangkan. Pengaturan seting pada ketinggian $100 \mathrm{~cm}$, ada kecenderungan bunyi yang dihasilkan dipersepsi lebih kasar dan berat atau dianggap terlalu tajam. Jatuhnya beberapa titik ke dalam air desertai seting yang tinggi membaut efek suara yang sangat bervariasi. Tumpahan yang kecil dan banyak bersifat lebih ringan dari tumpahan lebar dan solid, jatuhnya tidak bersamaan menimbulkan gemericik yang bervariasi. Demikian juga gelembung dan gelombang yang dihasilkan cenderung menimbulkan suara berisik, bergejolak yang memberi efek bersemangat bukan relaksasi.

4. Kondisi 1 dibandingkan dengan kondisi 5

Kedua jenis respon (persepsi dan emosi) memperlihatkan hasil yang sama yaitu signifikan. Kondisi 1 memiliki bentuk tumpahan melebar dan solid dengan debit air tumpahnya besar, sedangkan kondisi 5 memiliki bentuk tumpahan pada satu titik. Kedua kondisi disetting pada pada ketinggian $50 \mathrm{~cm}$. Setelah responden merespon kondisi 1 kemudian berpindah merespon kondisi 5 terjadi penaikan nilai respon. Responden merespon positif bunyi air yang dihasilkan dengan bentuk tumpahan satu titik. Volume tumpahan dengan debit air yang kecil cenderung menjadi daya tarik yang dipersipsikan ringan, sejuk, damai lebih halus yang cenderung memberi perasaan nyaman, relax, lega dan sejuk. Sejalan dengan penelitian ( J.Y. Joen, P.J.Lee, J.You, and J.Kang, 2012) ataupun ( L. Gabrun and T.T. Ali, 2013), disebutkan bahwa air dengan ketajaman rendah cenderung untuk mempromosikan ketenangan dan relaksasi. Gelombang yang dihasilkan tidak besar, begitu juga gelembung yang dihasilkan lebis sedikit sehingga dampak suara yang dihasilkan lebih tenang.

5. Kondisi 1 dibandingkan dengan kondisi 6

Perbandingan kondisi 1(tumpahan lebar, ketingian $50 \mathrm{~cm}$ ) dengan kondisi 6 (tumpahan 1 titik ketinggian $100 \mathrm{~cm}$ ) menghasilkan perbedaan nilai respon antara persepsi dengan emosi. Setelah merespon kondisi 1 kemudian berpindah pada kondisi 6 , terjadi peningkatan nilai respon pada respon persepsi dan penurunan nilai respon pada emosi. Volume tumpahan atau debit air memberi pengaruh pada persepsi terhadap kesan ringan, sejuk, damai, pelan ataupun halus, sedangkan ketinggian tumpahan memberi kesan tekanan yang lebih berat, terasa lebih kasar dan tajam yang mempengaruhi perasaan seperti ketidaknyamanan, tertekan, menjenuhkan.Tekanan tinggi dan berat tidak disarankan dalam mencapai ketenangan (Watt, dkk, 2009). 
6. Kondisi 2 dibandingkan dengan kondisi 3

Kedua jenis respon (persepsi dan emosi) memperlihatkan hasil yang sama yaitu tidak signifikan. Kondisi 2 memiliki bentuk tumpahan melebar dan solid sedangkan kondisi 3 memiliki bentuk tumpahan beberapa titik. Kondisi 2 diseting pada $100 \mathrm{~cm}$ sedangkan disetting pada ketinggian $50 \mathrm{~cm}$. Setelah responden merespon kondisi 2 kemudian berpindah merespon kondisi 3, terjadi penurunan nilai respon. Bunyi bervariasi yang dihasilkan dari tumpahan beberapa titik cenderung dinilai bergejolak, bising, berisik yang mempengaruhi emosi responden pada perasaan yang tidak nyaman atau kurang menyenangkan. Mungkin kondisi seperti ini akan dirasakan berbeda bila seting tempatnya berbeda misalnya untuk seting di luar ruangan. Tumpahan beberapa titik cenderung menghasilkan riak gelombang dan gelembung yang terus bergesekan memberi dampak bunyi yang bervariasi (Watt, 2009) dan cenderung dirasakan mengaggu untuk tujuan relaksasi.

7. Kondisi 2 dibandingkan dengan kondisi 4

Respon persepsi dan emosi menunjukkan nilai yang berbeda, pada respon persepsi dihasilkan nilai yang tidak signifikan sedangkan pada emosi dihasilkan nilai signifikan. Kondisi 2 dengan tumpahan lebar disetting pada ketinggian $100 \mathrm{~cm}$ sedangkan kondisi 4 dengan tumpahan beberapa titik disetting pada ketinggian $100 \mathrm{~cm}$. Setelah responden merespon kondisi 2 kemudian berpindah merespon kondisi 4 terjadi penurunan nilai respon untuk respon persepsi. Bunyi bervariasi yang dihasilkan dari tumpahan beberapa titik cenderung dinilai bergejolak, bising ataupun berisik. Kedua kondisi tersetting pada ketinggian $100 \mathrm{~cm}$.
Kondisi 2 dengan bentuk tumpahan lebar dan solid memerlukan debit air yang lebih besar dibanding dengan kondisi 4 (tumpahan beberapa titik) sehingga tekanan dan kecepatan air yang jatuh lebih besar dibanding kondisi 4, kesan berat dan deras ini menjadi respon negatif yang mempengaruhi respon emosi seperti perasaan tertekan ataupun stress. Dibandingkan dengan kondisi 4 yang terkesan lebih ringan, responden lebih memberi penilain positif pada respon emosi terhadap kondisi 4 daripada kondisi 2. Fenomena menjatuhkan volume air dengan seting tinggi cenderung dirasakan menekan, berat dan dirasakan memiliki kecepatan yang dirasakan sebagi efek deras (Galbrun, 2013).

8. Kondisi 2 dibandingkan dengan kondisi 5

Kedua jenis respon (persepsi dan emosi) memperlihatkan hasil yang sama yaitu signifikan. Kondisi 2 memiliki bentuk tumpahan melebar dan solid sedangkan kondisi 5 memiliki bentuk tumpahan 1 titik. Kondisi 2 diseting pada $100 \mathrm{~cm}$ sedangkan diseting pada ketinggian $50 \mathrm{~cm}$. Setelah responden merespon kondisi 2 kemudian berpindah merespon kondisi 5 , terjadi penaikan nilai respon. Bunyi pada kondisi 5 direspon lebih positif dibandingkan kondisi 2. Dengan bentuk tumpahan i titik, debit air yang kecil dan seting ketinggian $50 \mathrm{~cm}$ bunyi yang dihasilkan lebih lembut, geriak gelombang dan gelembung yang dihasilknan juga lebih kecil. Kondisi ini lebih mendukung tercapainya relaksasi, karena tekanan tinggi dan berat tidak disarankan dalam mencapai ketenangan (Watt,dkk, 2009)

9. Kondisi 2 dibandingkan dengan kondisi 6

Kedua jenis respon (persepsi dan emosi) memperlihatkan hasil yang 
sama yaitu signifikan. Kondisi 2 memiliki bentuk tumpahan melebar dan solid sedangkan kondisi 6 memiliki bentuk tumpahan 1 titik. Kondisi 2 diseting pada ketinggian yang sama yaitu $100 \mathrm{~cm}$. Setelah responden merespon kondisi 2 kemudian berpindah merespon kondisi 6 , terjadi penaikan nilai respon. Bunyi pada kondisi 6 direspon lebih positif dibandingkan kondisi 2. Dengan bentuk tumpahan 1 titik, debit air kecil menjadikan bunyi yang dihasilkan lebih lembut, geriak gelombang dan gelembung yang dihasilknan juga lebih kecil sehingga lebih mendukung pada kondisi yang tenang dan tekanan tinggi dan berat tidak disarankan dalam mencapai ketenangan (Watt,dkk, 2009).

10. Kondisi 3 dibandingkan dengan kondisi 4

Respon persepsi dan emosi menunjukkan nilai yang tidak signifikan, artinya setelah merespon kondisi 3 dan berpindah pada kondisi 4 terjadi penurunan nilai respon. Kondisi 3 dan kondisi 4 memiliki bentuk tumpahan yang sama yaitu tumpahan dengan beberapa titik, sedangkan seting untuk ketinggiannya berbeda. Kondisi 3 berada pada setting $50 \mathrm{~cm}$ dan seting 4 berada pada $100 \mathrm{~cm}$. Perbedaan ketinggian memberi pengaruh pada tekanan air ke tangki penampung air bawah (tank 2), yang membuat persepsi berat, lebih berisik, lebih menekan, terasa lebih deras dan menimbulkan bunyi yang lebih kasar. Demikian juga pengaruh terhadap respon emosi, perasaan tertekan dan perasaan tidak nyaman. Sehingga kondisi 4 direspon lebih negatif dari kondisi 3

11. Kondisi 3 dibandingkan dengan kondisi 5

Respon persepsi dan emosi menunjukkan nilai yang signifikan, artinya setelah merespon kondisi 3 dan berpindah pada kondisi 5 terjadi penaikan nilai respon. Kondisi 3 dan kondisi 5 memiliki setting ketinggian yang sama yaitu $50 \mathrm{~cm}$ sedangkan bentuk tumpahan berbeda. Kondisi 3 berupa tumpahan dengan beberapa titik sedangkan kondisi 5 memiliki tumpahan satu titik. Dalam penelitian Watt et al juga didukung penelitian Galbrun dan Ali dikatakan bahwa bunyi air yang keras atau tekanan tinggi tidak terlalu diperlukan untuk mencapai ketenangan.

Kondisi 5 dengan tumpahan 1 titik dan debit air cukup kecil mendapat respon positif terkait kesan ringan, lebih menyejukkan, damai, hening dan lebih halus. Demikian juga respon terhadap emosi mendapat apresiasi yang baik dari responden terkait perasaan senang, nyaman, segar, lebih lega, menjadi relax dan bahkan mengantuk.

12. Kondisi 3 dibanding dengan kondisi 6

Perbandingan kondisi 3 dan kondisi 6 menghasilkan respon persepsi yang signifikan dan respon emosi yang tidak signifikan. Kondisi 3 memiliki tumpahan air dengan beberapa titik dengan setting ketinggian pada level $50 \mathrm{~cm}$, sedangkan kondisi 6 dengan tumpahan 1 titik dengan seting ketinggian $100 \mathrm{~cm}$. Perpindahan dari kondisi 3 ke kondisi 6 mendapat penaikan respon terhadap karakteristik air, kondisi 6 dinilai lebih positif dari kondisi 3. Dengan debit tumpahan yang kecil memberi dampak bunyi yang lebih ringan, lebih memberi kesan damai, terasa lebih hening, pelan dan lebih halus. Sementara setting ketinggian 100 $\mathrm{cm}$ memberi pengaruh terhadap respon emosi responden. Terjadi nilai yang tidak signifikan artinya responden lebih merespon positif kondisi 3 daripada kondisi 6. Bunyi yang dihasilkan dari setting $100 \mathrm{~cm}$ lebih konstan sehingga banyak responden merespon membosankan. Dampak ketinggian 
juga direspon menghasilkan bunyi yang lebih kasar sehingga ada respon negatif pada emosi seperti tertekan, dan beberapa perasaan tidak nyaman.

13. Kondisi 4 dibandingkan dengan kondisi 5

Respon persepsi dan respon emosi menunjukkan nilai signifikan. Kondisi 4 memiliki bentuk tumpahan beberapa titik dan terseting pada ketinggian $100 \mathrm{~cm}$ sedangkan kondisi 5 memiliki bentuk tumpahan 1 titik dan tersetting $50 \mathrm{~cm}$. Setelah responden merespon kondisi 4 dan berpindah merespon kondisi 5 ternyata terjadi kenaikan nilai respon. Berarti kondisi 5 direspon lebih positif dibanding kondisi 4. Debit tumpahan lebih kecil direspon positif karena memberi persepsi ringan, menyegarkan, terasa damai, menenangkan, pelan dan memberi karakter halus demikian juga pengaruhnya terhadap respon emosi. Kondisi 5 dianggap memberi rasa nyaman, menyenangkan, menyegarkan, membuat lebih relak sampai mengantuk. Pada beberapa penelitian ( J.Y. Joen, P.J.Lee, J.You, and J.Kang, 2012) ataupun ( L. Gabrun and T.T. Ali, 2013), disebutkan bahwa air dengan ketajaman rendah cenderung untuk mempromosikan ketenangan dan relaksasi

14. Kondisi 4 dibanding dengan kondisi 6

Respon persepsi dan respon emosi masing-masing menunjukkan nilai signifikan dan tidak signifikan. Kondisi 4 memiliki bentuk tumpahan beberapa titik dan tersetting pada ketinggian $100 \mathrm{~cm}$ sedangkan kondisi 6 memiliki bentuk tumpahan 1 titik dan tersetting $100 \mathrm{~cm}$. Setelah responden merespon kondisi 4 dan berpindah merespon kondisi 6 ternyata terjadi kenaikan nilai respon untuk respon persepsi sedangkan pada respon emosi terjadi penurunan nilai respon. Berarti untuk respon persepsi kondisi 6 direspon lebih positif dibanding kondisi 4 sedangkan pada respon emosi, kondisi 6 direspon lebih negatif dari kondisi 4 . Dengan debit tumpahan yang kecil memberi dampak bunyi yang lebih ringan, lebih memberi kesan damai, terasa lebih hening, pelan dan lebih halus. Sementara setting ketinggian 100 $\mathrm{cm}$ memberi pengaruh terhadap respon emosi responden. Terjadi nilai yang tidak signifikan artinya responden lebih merespon positif kondisi 4 daripada kondisi 6. Bunyi yang dihasilkan dari setting $100 \mathrm{~cm}$ terlalu konstan sehingga banyak responden merespon membosankan. Dampak ketinggian juga direspon menghasilkan bunyi yang lebih kasar sehingga ada respon negatif pada emosi seperti tertekan, dan perasaan tidak nyaman.

15. Kondisi 5 dibandingkan dengan kondisi 6

Kondisi 5 dan kondisi 6 memiliki bentuk tumpahan yang sama, yang membedakan adalah setting ketinggian, masing-masing adalah 50 $\mathrm{cm}$ dan $100 \mathrm{~cm}$. Perbandingan kondisi 5 dengan kondisi 6 mengalami penurunan nilai respon, artinya responden lebih memberi respon positif kondisi 5 daripada kondisi 6. Bunyi air yang dihasilkan dari kondisi 6 (setting 100 $\mathrm{cm}$ ) direspon / terdengar lebih kasar, lebih berisik dan terkesan lebih berat di banding bunyi yang dihasilkan dari kondisi 5. Demikian juga pengaruhnya terhadap respon emosi, bunyi yang dihasilkan dari kondisi 6 direspon lebih terasa menekan dibandingkan dari bunyi kondisi 5 .

Pembuktian Hipotesa penelitian Berdasarkan tabel Uji Linier untuk persepsi dan emosi, kedua tabel menghasilkan perbedaan nilai yang signifikan. Pada angka 0.000 berada dibawah nilai signifikan ( $\mathrm{p}<0,05)$. Sugiyono (2012) menjelaskan bahwa 
hipotesa akan diterima jika nilai signifikansinya kurang dari 0.05 . Nilai 0,000 mengindikasikan bahwa terjadi perbedaan respon akibat pengkondisian stimulus dengan kombinasi bentuk tumpahan dan ketinggian. Hubungan perbandingan antara masing-masing kondisi memberi gambaran bagaimana kedua variabel saling mempengaruhi.

Sementara dari 6 hipotesa yang paling mewakili dan cenderung menunjang emosi yang positif adalah hipotesa 5 karena cenderung membawa perubahan ke arah restorasi positif. Sebaliknya hipotesa 2 walaupun terbukti memberi dampak perubahan namun dampak restorasi cenderung ke arah negatif.

D.2.Perbedaan respon terhadap stimulus eksperimen

D.2.1. Perbedaan bentuk tumpahan / debit air tumpahan

Dari serangkaian eksperimen dan hasil pengolahan data, tercatat bahwa kondisi yang cenderung mendapat respon positif adalah kondisi 5 (tumpahan 1 titik, ketinggian $50 \mathrm{~cm}$ ) sedangkan kondisi yang cenderung kurang disukai adalah kondisi 2 (tumpahan lebar, ketinggian $100 \mathrm{~cm}$. Dari 3 jenis bentuk tumpahan (tumpahan lebar solid, tumpahan beberapa titik, dan tumpahan 1 titik), dapat dilihat urutan debit air tumpahan terbesar sampai terkecil. Debit air yang besar ada pada bentuk tumpahan lebar solid, kemudian yang kedua adalah bentuk beberapa titik. Bentuk tumpahan 1 titik merupakan tumpahan dengan debit paling kecil. Dari ketiga stimulus bentuk tumpahan tercatat bentuk tumpahan yang ketiga (tumpahan 1 titik) cenderung mendapat respon paling positif diantara stimulus lainnya. Kecenderungan respon tersebut terlihat dari persepsi terkait sifat berat-ringan, bising-tenang, berisik-hening, tertekanlega, sifat deras- pelan atau kasar-halus termasuk berbagai kecenderungan perasaan yang ditimbulkan seperti, tidak senang-senang, stres-relak, tidak nyaman-nyaman, melelahkanmenyegarkan, bersemangatmengantuk, tertekan-lega, atau pengapsejuk.

Bentuk tumpahan 1 titik (debit air tumpahannya paling kecil) terdapat pada kondisi 5 dan kondisi 6 yang mendapat kecenderungan respon positif. Sementara kondisi 1 dan kondisi 2 , sering direspon negatif oleh responden terkait karakteristik berat, deras ataupun bunyi yang terasa kasar. Kakateristik fisik air seperti yang dikategorisasi oleh Laurent Galbrun dan Calarco (2014) memberi dampak yang cukup kuat terhadap respon persepsi responden.

ketinggian

D.2.2. Perbedaan seting

Pencatatan dan olah data dari serangkaian eksperimen menunjukkan bahwa kondisi yang cenderung memberi respon positif adalah kondisi 5 (tumpahan 1 titik, ketinggian $50 \mathrm{~cm}$ ) sedangkan kondisi yang cenderung kurang disukai adalah kondisi 2 (tumpahan lebar, ketinggian $100 \mathrm{~cm}$. Dari perbedaan setting ketinggian antara $50 \mathrm{~cm}$ dan $100 \mathrm{~cm}$, responden cenderung memberi peningkatan nilai ketika merespon kondisi dengan setting $50 \mathrm{~cm}$. Respon positif itu umumnya terkait pada karakteristik tehadap beratringan, bising-tenang, berisik-hening, tertekan-lega, deras-pelan ataupun kasar-halus yang mempengaruhi perasaan terkait pada tidak senangsenang, stres-relak, tidak nyamannyaman, melelahkan-menyegarkan, bersemangat-mengantuk, tertekan-lega, atau pengap-sejuk. Seting rendah cenderung mendapat penilain lebih positif dari seting tinggi 


\section{E. DISKUSI}

Hasil perangkingan / leveling terhadap ke enam kondisi diuraikan dari respon paling positif ke respon paling negatif, yaitu:

Untuk respon persepsi; kondisi 5 - kondisi 6- kondisi 1- kondisi 3 kondisi 4 - kondisi 2.

Untuk respon emosi; kondisi 5 kondisi 6 - konndisi 4 - kondisi 3 kondisi 1- kondisi 2.

Kondisi 5 dan 6 memiliki bentuk tumpahan satu titik sebagai perwakilan dari volume tumpahan kecil berada pada level diatas garis rata-rata, kondisi 4 dan 3 memiliki bentuk tumpahan beberapa titik sebagai perwakilan dari volume sedang, sementara kondisi 1 dan 2 dengan bentuk tumpahan melebar sebagai perwakilan volume tumpahan besar.

\begin{tabular}{|l|r|r|r|r|r|r|r|}
\hline & kondisi 1 & kondisi 2 & \multicolumn{2}{c|}{ kondisi 3} & kondisi 4 & kondisi 5 & \multicolumn{2}{l|}{ kodisi 6 } \\
\hline LOW (100-400 Hz) & 65,1 & 69,3 & 62,3 & 66,7 & 57,6 & 60,5 \\
\hline MID $(500-1600)$ & 62,4 & 68,2 & 70,9 & 72,8 & 56,6 & 63,7 \\
\hline HIGH $(2000-8000 \mathrm{~Hz})$ & 65,0 & 71,4 & 69,4 & 73,4 & 61,6 & 65,3 \\
\hline
\end{tabular}

Pada frekuensi rendah, kondisi 5 memiliki level energi atau tingkat tekanan suara paling rendah, sedangkan kondisi 2 memiliki level energi atau tingkat tekanan suara paling tinggi. Sementara pada frekuensi menengah dan tinggi kondisi 4 memiliki tingkat tekanan suara paling tinggi.

\begin{tabular}{|l|c|c|c|c|c|c|}
\hline & kondisi 1 & kondisi 2 & kondisi 3 & kondisj 4 & kondisj 5 & kondisj. 6 \\
\hline OVERALL & 69,3 & 74,9 & 73,8 & 76,9 & 64,2 & 68,7 \\
\hline
\end{tabular}

Untuk semua frekuensi, terlihat seting ketinggian memberi pengaruh terhadap tingkat tekanan suara. Pada volume tumpahan besar (kondisi 1 dan 2), kondisi 2 diseting lebih tinggi $(100 \mathrm{~cm})$ memiliki tingkat tekanan suara lebih tinggi dari kondisi $1(50 \mathrm{~cm})$. Untuk volume tumpahan sedang, kondisi 4 yang diseting lebih tinggi $(100 \mathrm{~cm})$, memiliki tingkat tekanan suara lebih tinggi dari kondisi 3
$(50 \mathrm{~cm})$. Begitu juga untuk tumpahan kecil, kondisi 6 memiliki tekanan lebih tinggi dari kondisi 5. Seting yang lebih tinggi dan volume tumpahan yang lebih besar menghasilkan level energi atau tingkat tekanan suara yang lebih tinggi dari pada seting yang lebih rendah serta volume tumpahan lebih kecil.

Respon persepsi dapat diurutkan dari nilai paling positif ke negatif adalah . Kondisi 5,1dan 3 mewakili seting rendah sedangkan 4 dan 2 mewakili seting yang tinggi. Apabila dikaitkan dengan penilaiaan yang dilakukan Galbrun dan Calarco terhadap karakteristik fisik air maka ditemukan beberapa karakter yang mempengaruhi respon negatif terhadap seting tinggi yaitu: bunyi dirasakan berat, bergejolak, menghasilkan bunyi berisik atau bising, dipersepsi deras dan dirasakan kasar. Jadi dapat dikatakan kondisi dengan seting yang rendah cenderung

\section{DAFTAR PUSTAKA}

Arsyad, S. (2000): Konservasi Tanah dan Air, Bandung-Penerbit IPB (IPBPress).

Booth, Norman K (1990): Basic element of landscape architectural design, Waveland-Prospect Height.

Chaplin, J.P (2006):Kamus Lengkap Psikologi, Jakarta-Publisher

Goldstein, E. Brucc (2010): Sensation and Perception, Eight Edition, United States of America Wadsworth

Setiawan, Hariyadi B.(1996): Arsitektur Lingkungan dan Prilaku, Yogyakarta-Direktorat Jendral Pendidikan Tinggi

Sugiyono,(2011): Metode Penilaian Kuantitatif, Kualitatif dan R \& O, Bandung-Alfabeta

Syukur (2011): Beragam cara terhapy; 
gangguan sehari-hari, Yogyakarta-Duva Press.

Wylson, Anthony (1986):Aquatecture: Architecture and water, The University of California-Publiser Architectural Press.

Calarco, F.M.A., \& Galbrun, L. (2014): Semantic assesment of water features used over roadtraffic noise, Paper presented at Forum Acusticum 2014, Krakow, Poland

G. Watts, R. Pheasant, K Horoshenkov, L. Ragonesi, (2009): Measurement andsubjective assessment of water generated sounds, Acta Acust. United with Acust. 95, 1032-1039

J. Kang, Taylor dan Francis(2007): Urbarn Sound Environment, New York

J.Y. Jeon, P.J. Lee, J.You, J. Kang, (2010): Perpectual assessment of quality of urbansoundscapes with combined noise sources and water sounds, J. Acoust. Soc. Am. 127(3), 1357-1366)

J.Y. Jeon , P.J. Lee, J. You, dan J. Kang (2012): Acoustical characteristics of water sounds for soundscapes enhancement in urban open spaces, J. Acoust. Soc. Am. 131 2101-2109.

Lunden, peter \& Nilsson, mats (2015): Perceptual and phsycoacustik, Faculty of Social Sciences,Departement of Psicoloagy

L. Galbrun dan T.t. Ali(2013):Acoustical and perpectual assesment of water sounds and their use over road traffic noise, J. Acoust. Soc. Am. 133 227-237

L. Galbrun, T.T. (2011): Acoustic design of water feautures forthe built environment, Proceeding of the Institute of Acoustics, 33(4), 112-
119, Acoustics 2011, Glasgow, 14-15 September

Laurent Galbrun, Tahrir Ali (2012): Perpectual assesment of water sounds for road traffic noise masking, Societe Francaise d'Acoustique, Acoustics, Apr 2012, Nantes, Fauce (hal 00811210)

Maufeld dan Heyer (2003): Colour Perseption: Mind and the physical world, Oxford University Press.

Nave, R (2003): Description of motion, Hyperphysics. 